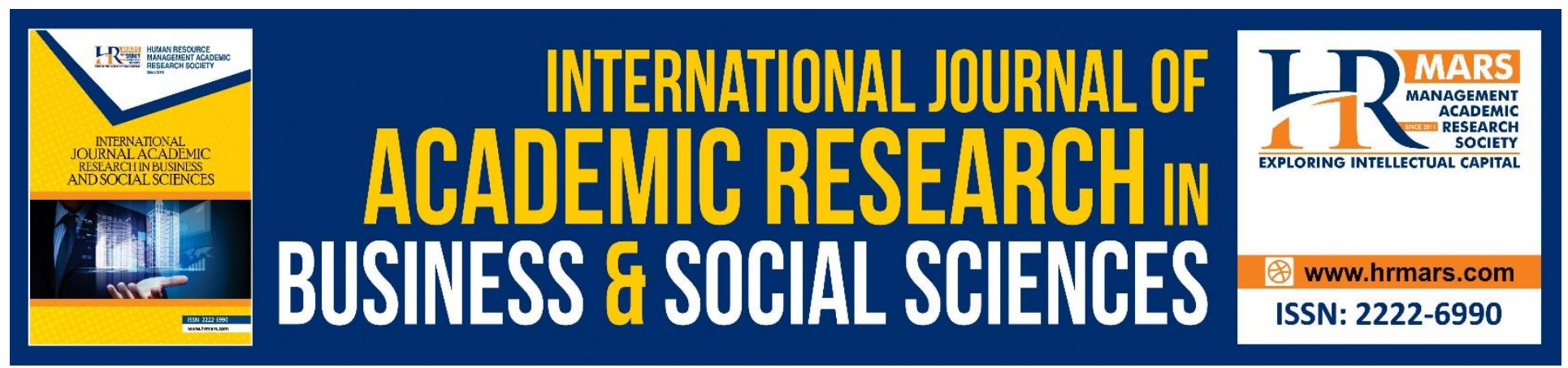

\title{
The Influence of Transformational Leadership, Organizational Culture and Trust on the Organizational Citizenship Behaviour of Agricultural Service, Banten Province
}

Aan Muawanah, Dedi Purwana, and Muchlis R. Luddin

To Link this Article: http://dx.doi.org/10.6007/IJARBSS/v10-i14/7692

DOI:10.6007/IJARBSS/v10-i14/7692

Received: 05 April 2020, Revised: 10 May 2020, Accepted: 15 June 2020

Published Online: 24 July 2020

In-Text Citation: (Muawanah et al., 2020)

To Cite this Article: Muawanah, A., Purwana, D., \& Luddin, M. R. (2020). The Influence of Transformational Leadership, Organizational Culture and Trust on the Organizational Citizenship Behaviour of Agricultural Service, Banten Province. International Journal of Academic Research in Business and Social Sciences, 10(14), 238-245.

Copyright: (C) 2020 The Author(s)

Published by Human Resource Management Academic Research Society (www.hrmars.com)

This article is published under the Creative Commons Attribution (CC BY 4.0) license. Anyone may reproduce, distribute, translate and create derivative works of this article (for both commercial and non-commercial purposes), subject to full attribution to the original publication and authors. The full terms of this license may be seen

at: http://creativecommons.org/licences/by/4.0/legalcode

Special Issue: WSTI2018 - Issues and Trends on Education, Science and Technology, 2020, Pg. 238 - 245 http://hrmars.com/index.php/pages/detail/IJARBSS JOURNAL HOMEPAGE

Full Terms \& Conditions of access and use can be found at http://hrmars.com/index.php/pages/detail/publication-ethics 


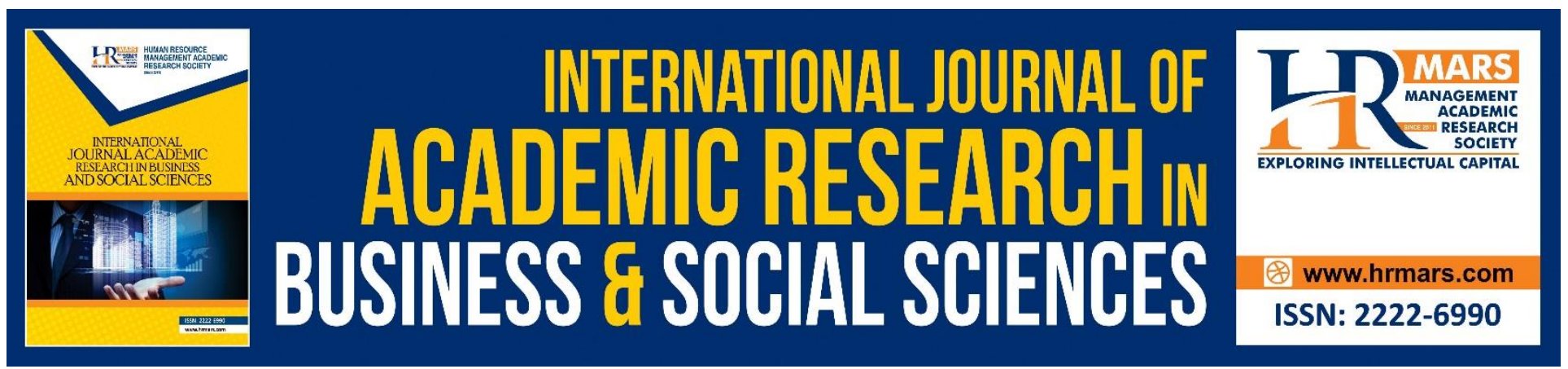

\title{
The Influence of Transformational Leadership, Organizational Culture and Trust on the Organizational Citizenship Behaviour of Agricultural Service, Banten Province
}

\author{
Aan Muawanah, Dedi Purwana, and Muchlis R. Luddin \\ State University of Jakarta, Indonesia
}

\begin{abstract}
The purpose of this study was to determine the influence of transformational leadership, organizational culture, and trust in organizational citizenship behavior of Banten Province Agriculture Service Employees. This study tries to answer the problem of organizational citizenship behavior with increasing evidence of employee service. The study was conducted on organizational citizenship behavior involving 144 Banten Province Agricultural Service employees who have been selected from the target population of the Banten Province Agricultural Service employees using a quantitative approach with path analysis methods. Hypothesis testing research shows: transformational leadership has a direct positive effect on organizational citizenship behavior; organizational culture has a direct positive effect on organizational citizenship behavior; trust has a direct positive effect on organizational citizenship behavior transformational leadership has a direct positive effect on trust: organizational culture has a direct positive effect on trust: transformational leadership has a direct positive effect on organizational culture: because it is to improve the organizational citizenship behavior of employees of the Banten Provincial Agriculture Office, transformational leadership, organizational culture and trust need to be improved.
\end{abstract}

Keywords: Transformational Leadership, Organizational Culture, Trust, Organizational Citizenship Behavior.

\section{Introduction}

Transformational leadership has been constantly attracting the interest of scientists because of its association with motivation and work satisfaction, leadership effectiveness, extra-role behaviour and performance. Research results demonstrate the importance of extra-role behaviour to employees' environment in an organization. This may help speed up the organization's development.

The Office of Agriculture of the Province of Banten as a state actor is part of the national development planning system, which is in agreement with the mandate of Law Number 25 of 2004 on the National Development Planning System. The national development planning system may run 
well if all state actors and community members at central and regional levels are able to form a solid procedure for development planning in long-, medium- and short-term development plans. This can be realized if all employees perform their tasks and functions appropriately and assist each other in their work performance (OCB).

According to the results of the Workload Analysis (ABK), the Office of Agriculture of the Province of Banten is still in need of 18 civil servants with favourable OCB. However, according to the results of the survey and interview with the head of division and head of centre, only 16 out of 176 civil servants (or 1 per cent of the total number of civil servants) has favourable OCB. This can stand in the Office of Agriculture's way to achieve its vision and missions. Thus, it is necessary to gain support from all elements, starting from the leader to the lowest-positioned employees.

Furthermore, data shows deviations of the budget realization from the target at the Office of Agriculture, and the highest deviation occured in the Budget Year 2016 at 37.15 per cent. Organizational citizenship behaviour, which refers to intentional and discretionary behaviours enhancing the context of job performance, has been acknowledged by scholars and practitioners as a pivotal source in the organization's functions and effectiveness. In performing its functions, the Office of Agriculture encounters a number of stumble blocks. Many of the executing staff members are perceived to have yet to show off maximum performance. Besides, there has been obvious sectoral ego among the staff members who feel that they are not connected to other divisions or sections. Many factors are responsible for this. Trust in leaders refers to employees' conviction in their leaders regarding policies, contacts and feelings about a wide range of matters, including facilities provided for them to make a living. The central importance of interpersonal trust for sustaining team and organisational effectiveness is increasingly being recognised. Employees' trust in their leaders has been related to a range of productivity-related processes and outcomes, such as the quality of communication and problem-solving, discretionary effort and organisational citizenship behaviour. A problem arises when the level of employees' trust in their leaders is low due to discrepancies between the educational background, competencies and skills of the leaders and their positions. It has been recorded that 20 out of 46 officials (43 per cent) at the Office of Agriculture of the Province of Banten have unsuited competencies and educational background (Appendix 9). In addition, it is deemed necessary to improve employees' motivation as there have been some occasions at which employees are found to be unmotivated to complete their works. This has fall short of the expectation of the organization and the Province of Banten Government who has increased the work benefits for them.

Employees' trust in leaders is closely linked with productivity-related processes and outcomes, for example, communication and problem-solving, organizational citizenship behaviour and organizational commitment. Agbejule (2011) points out that the main discussion is that if an organization maintains a strong culture by demonstrating a well-integrated and effective set of specific values, beliefs and behaviours, then it will perform at a higher level of productivity. Human resources are the key to the success of organization-initiated changes. The success and failure of an organization also depend on the quality of the leader appointed to lead the organization. Leaders are responsible for setting goals, coordinating changes and nurturing contacts between individuals. Organizational culture plays a part in this. Organizational culture provides individuals with directions to improve their abilities, commitment, loyalty and extra-role behaviour, including helping colleagues, maintaining the organization's facilities, obeying the prevailing rules, having tolerance 
towards others, restraining from complaining, providing suggestions for betterment and working in a time-effective manner.

These all may influence the outcomes of employees' works, for example lowering their productivity and performance. For this reason, the authors were interested in discussing the OCB of the employees of the Office of Agriculture of the Province of Banten.

\section{Literature Review}

\section{Organizational Citizenship Behaviour}

Organizational behaviour refers to the science of human behaviours in an organization and how such behaviours leave an impact on the organization. Organ defines OCB as an individual behaviour that is discretionary, not directly and explicitly received an award from the formal system, and overall effectiveness encourage organizational functions. It is free and voluntary; as such behaviour is not required by the requirements of the role or job description but as a personal choice. Chen et al., (2006) states that organizational citizenship behaviour (OCB) represents individual behaviour that is discretionary, not directly or explicitly recognized by the formal reward system, and in the aggregate promotes the efficient and effective functioning of the organization. Unrestricted and spontaneous individual behaviours resulted from one's character or the character of a work or an organization also originates from the relationship with leaders. These behaviours are addressed to the organization or colleagues and lead to increased organizational effectiveness achieved directly from the work or indirectly from intensifying interpersonal relationships. Citizenship behaviours are neither described in formal works nor rewarded under contract.

According to the description above, the definition of OCB can be synthesized as a collection of employees' going-above-and-beyond behaviours in effectively achieving goals for the benefit of the organization with the following indicators: altruism, conscientiousness, sportsmanship, courtesy and civic virtue.

\section{Transformational Leadership}

The transformational leadership theory was first proposed by James McGregor Burns in 1979 in his Pulitzer Price and National Book Award winning book entitled Leadership. In this book, Burns (1979) uses the term transformational leadership, in which leadership is transformed from leaders to the followers. James McGregor Burns, a political scientist, first coined the term transformational leadership when he was pursuing his studies in the U.S. He found a rarely used leadership style. Yukl (2013) states that with transformational leadership, the followers fell trust, admiration, loyalty and respect towards the leader and they are motivated to do more than they are originally expected to do. The leader transforms and motivates followers by making them more aware of the importance of task outcomes, inducing them to transcend their own self-interest for the sake of the organization or team and activating their higher order needs. A leader who has the attributes of a transformational leader will constantly strive to expand and increase the number of followers and encourage them to put common interest first for the sake of mutual benefit. Hellriegel and Slocum (2011) state that transformational leadership involves anticipating future trends, inspiring followers to understand and embrace a new vision of possibilities, developing others to leaders or better leaders and building the organization or group into community of challenged and rewarded learners.

According to the description above, the definition of transformational leadership can be synthesized as the behaviour of a leader who strives to optimally empower the resources of an 
organization to achieve a meaningful goal in accordance with the predetermined target with the following indicators: able to influence subordinates, inspiring, stimulating intellectualism and considerate.

\section{Organizational Culture}

Edgar H. Schein in his book 'Organizational Culture and Leadership' in 2016 defines organizational culture as a pattern of shared basic assumptions that a group has learned as it solved its problems of external adaptation and internal integration, that has worked well enough to be considered valid and, therefore, to be taught to new members as the correct way to perceive, think, and feel in relation to those problems. He, in his work "organizational culture and leadership" widely used as a reference on organizational culture, further defines organizational culture in a more general way as a pattern of basic assumptions invented, discovered developed by a given group as it learns to cope with its problems of external adaptation and internal integration that has worked well enough to be considered valuable and therefore to be taught to new members as the correct way to perceive, think and feel in relation to those problems. Organizational culture is a set of assumptions and values that are realized or not realized and able to build an integration within an organization. Organizational culture consists of the values and assumptions shared within an organization. It defines what is important and unimportant in the company and consequently, directs everyone in the organization toward the right way of doing things.

According to the description above, the definition of organizational culture can be synthesized as a set of values and norms shared and strongly adhered to by members of an organization to be used as a guide to performing works that support the achievement of the organizations' goals with the following indicators: shared values, shared norms and shared assumptions.

\section{Trust}

Trust is one's willingness to rely on another person to whom they believe in. Trust refers to a mental condition which is based on one's situation and social context. When taking a decision, they will be inclined to base their decision on the consideration of those they trust as opposed to those they do not trust. Richard (2015) defines trust as a psychological state comprising the intention to accept vulnerability based upon positive expectations of the intentions or behaviour of another. Colquitt et al., (2011) defines trust as the willingness to be vulnerable to an authority based on positive expectations about the authority's actions and intentions. Trust is one's judgment on their relationship with others with whom they will make a given transaction based on expectations in an environment that is rife with uncertainty.

According to the description above, the definition of trust can be synthesized as one's willingness to be vulnerable to an authority based on positive expectations about the author's actions and concerns with the following indicators: trust in the authority's good intentions, trust in the authority's abilities, trust in the authority's performance and trust in the authority's behaviours in building relationships.

\section{Research Method}

This research used survey method with path analysis technique (path analyses). The data of this research were collected by selecting the sample in the population. The affordable population in this study is the entire employee Banten Province Agriculture Service which amounts to 225 
employee. And calculations using slovin, then obtained a total sample of 114 employee frame sampled in this study. Data collection used for this research is descriptive statistics and inferential statistics.

\section{Results and Discussions}

\section{Direct Positive Effect of Transformational Leadership on OCB}

The path coefficient of the effect of transformational leadership on OCB was 0.277 with a $t_{\text {count }}$ value of 4.05 . The $t_{\text {count, }}$ therefore, was greater than $t_{\text {table }}$ at $d k=140$ for $\alpha=0.05$ of 1.98 . Thus, $H_{0}$ was rejected and $\mathrm{H}_{1}$ was accepted, meaning that there was a significant, direct positive effect of the variable transformational leadership on the variable OCB.

Sumi Jha, quoting Bass, states that leadership is an essential factor affecting the employees' behaviours in a significant way. Leadership is an important factor contributing to successful behavioural transformation. Transformational leadership shapes employees behaviour and prepares them to be competitive. Transformational leadership behaviour influences several organizational variables, for example perceiving extra effort, OCB, and job satisfaction.

\section{Direct Positive Effect of Organizational Culture on OCB}

The path coefficients of organizational culture on OCB was 0.286 with a $t_{\text {count }}$ value of 4.18 . The $t_{\text {count, }}$, therefore, was greater than $t_{\text {table }}$ at $d k=140$ for $\alpha=0.05$ of 1.98 . Thus, $H_{0}$ was rejected and $\mathrm{H}_{1}$ was accepted, meaning that there was a significant, direct positive effect of the variable organizational culture on the variable OCB.

This is consistent with the results of the research by Khalili (2017), showing that organizational culture has a significant effect on $O C B$. $O C B$ is important in promoting organizational effectiveness. The absence of OCB may generate negative outcomes, leading to organizational dysfunction such as a decline in work performances, absenteeism, and high turnover. The belief among theorists is that as more employees engage in $\mathrm{OCB}$, the organization becomes more successful. Therefore, factors influencing $O C B$ have been the central theme of many past OCB researchers. Organizational culture can influence OCB.

\section{Direct Positive Effect of Trust on OCB}

The path coefficients of trust on OCB was 0.327 with a $t_{\text {count }}$ value of 4.66 . The $t_{\text {count, }}$ therefore, was greater than $t_{\text {table }}$ at $d k=140$ for $\alpha=0.05$ of 1.98 . Thus, $H_{0}$ was rejected and $H_{1}$ was accepted, meaning that there was a significant, direct positive effect of the variable trust on the variable OCB.

Trust in an organization is associated with what an organization deems right or what is commonly known as organizational citizenship behaviour among employees. Yukl (2013) states that research has shown that trust in leadership is significantly related to positive job outcomes including job performance, organizational citizenship behaviour, job satisfaction and organizational commitment.

\section{Direct Positive Effect of Transformational Leadership on Trust}

The path coefficients of the effect of transformational leadership on trust was 0.262 with a $t_{\text {count }}$ value of 3.31. The $t_{\text {count, }}$, therefore, was greater than $t_{\text {table }}$ at $d k=141$ for $\alpha=0.05$ of 1.98 . Thus, $\mathrm{H}_{0}$ was rejected and $\mathrm{H}_{1}$ was accepted, meaning that there was a significant, direct positive effect of the variable transformational leadership on the variable trust. 
These results are in agreement with the opinions of some experts, including Montani \& Dagenais-Desmarais (2018) who state that this process of identification leads to the internalization of values, beliefs and goals held by the leader. As it happens, in the workplace, this tends to coincide with organizational success. expose theoretical reasons to expect a positive relationship between transformational leadership and positive employee behaviours, such as empowered behaviours. Followers who attribute strong positive characteristics to their leader (such as the ones evoked by the transformational leader behaviors).

\section{Direct Positive Effect of Organizational Culture on Trust}

The path coefficients of the effect of organizational culture on trust was 0.273 with a $t_{\text {count }}$ value of 3.46. The $t_{\text {count, }}$ therefore, was greater than $t_{\text {table }}$ at $d k=141$ for $\alpha=0.05$ of 1.98 . Thus, $H_{0}$ was rejected and $\mathrm{H}_{1}$ was accepted, meaning that there was a significant, direct positive effect of the variable organizational culture on the variable trust.

This proves idea as quoted by Kinicki and Williams (2011) that organizational culture, sometimes called corporate culture, is a sistem of shared beliefs and values that develops within an organization and guides the behaviour of its members. Trust is a positive expectation of a person in relation to words, actions, delegation of tasks and authorities to others according to the achievement of an organization's goals.

\section{Direct Positive Effect of Transformational Leadership on Organizational Culture}

The path coefficients of the effect of transformational leadership on organizational culture was 0.257 with a tcount value of 3.16. The tcount, therefore, was greater than ttable at $d k=142$ for $\alpha=0.05$ of 1.98 . Thus, $\mathrm{HO}$ was rejected and $\mathrm{H} 1$ was accepted, meaning that there was a significant, direct positive effect of the variable transformational leadership on the variable organizational culture.

These results are in agreement with the opinions of some experts, including Richard (2015) who states that transformational leadership is characterized by the ability to bring about significant change in both followers and the Organization. Transformational leaders have the ability to lead changes in an organization's vision, strategy and culture as well as promote innovation in products and technologies.

\section{Conclusion}

Conclusion: Firstly, transformational leadership has a direct positive effect on organizational citizenship behaviour (OCB). This means that appropriate adoption of the transformational leadership approach may improve the OCB of the employees working at the Office of Agriculture of the Province of Banten. Secondly, organizational culture has a direct positive effect on OCB. This means that a favourable organizational culture developing at the Office of Agriculture may improve the employees' OCB. Thirdly, trust has a direct positive effect on OCB. In other words, the higher the employees' trust in the organization, the higher their OCB. Fourthly, transformational leadership has a direct positive effect on trust. This means that the implementation of transformational leadership at the Office of Agriculture of the Province of Banten may improve the employees' trust. Fifthly, organizational culture has a direct positive effect on trust. This suggests that improved culture at the Office of Agriculture will result in improved employees' trust. Sixthly, Transformational leadership has a direct positive effect on organizational culture, meaning that transformational leadership may 
create a conducive organizational culture. Suggestions: 1) The Head of the Office of Agriculture of the Province of Banten should evaluate the leadership style currently adopted and consider reorienting the leadership style to transformational leadership. OCB can generally be improved through the improvement of organizational commitment. Organizational commitment can be improved by increasing the amount of compensations and other rewards and applying the performance-based benefit instruments. 2) Employees' discipline with regard to attendance time and dress code should be monitored and improved. Moreover, the employees' OCB can be improved by socializing the vision, missions, goals and values of the Office of Agriculture of the Province of Banten to all employees and improving the employees' organizational commitment in the form of a sense of belonging, sense of togetherness and loyalty through continuous, formal or informal meetings.

\section{References}

Agbejule, A. (2011). Organizational culture and performance: the role of management accounting system, Journal of Applied Accounting Research, 12.1 (2011), 74-89 https://doi.org/10.1108/09675421111130621

Burns, J. M. (1979). Leadership. Indiana University: Harper \& Row.

Colquitt, J. A., Lepine, M. J., \& Wesson. (2011). Organizational behavior: Improving performance and commitment in the workplace. McGraw-Hill Irwin, 2011.

Chen, J. C., Silverthorne, C., \& Hung, J. Y. (2006). Organization communication, job stress, organizational commitment, and job performance of accounting professionals in Taiwan and America. Leadership \& Organization Development Journal, 27, 242-249.

Edgar, H. S. (2016). Organizational Culture and Leadership. John Wiley \& Sons Inc. New York, United States

Helliegel, D., \& Slocum, J. W. (2011). Organizational Behavior 13 edition. USA: South Western Cengange Learning, 2011.

Khalili, A. (2017). Transformational leadership and organizational citizenship behavior, Leadership \& Organization Development Journal, 2017, LODJ-11-2016-0269 https://doi.org/10.1108/LODJ-11-2016-0269

Kinicki, A., \& William, B. (2011). Management a Practical introduction. New York: McGraw-Hill, 2011.

Montani, F., \& Dagenais-Desmarais, V. (2018). Unravelling the relationship between role overload and organizational citizenship behaviour: A test of mediating and moderating effects. European Management Journal, 2018. https://doi.org/10.1016/j.emj.2018.03.001

Richard L. D. (2015). The Leadership Experience 6 edition. USA: Cengage Learning, 2015. Yukl, A. G. (2013). Leadership in Organizations 8 Edition. New England: Pearson, 2013. 